\title{
Correction to: Mutagenesis mediated by CRISPR/Cas9 in the red imported fire ant, Solenopsis invicta
}

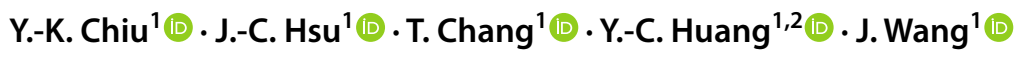

Published online: 17 July 2021

(c) International Union for the Study of Social Insects (IUSSI) 2021

\section{Correction to: Insectes Sociaux (2020) 67:317-326 https://doi.org/10.1007/s00040-020-00755-8}

The authors wish to correct an error that appeared in their article

Mutagenesis mediated by CRISPR/Cas9 in the red imported fire ant, Solenopsis invicta. Insectes Sociaux volume 67, pages 317-326 (2020)

The following sentence in the Methods section contains incorrect units:

"For most injection batches we used $30 \mathrm{ng} / \mu \mathrm{l}$ of sgRNA and $300 \mu \mathrm{g} / \mu \mathrm{l}$ of Cas 9 protein; for a few injection batches we used less $(15 \mathrm{ng} / \mu \mathrm{l}$ and $150 \mu \mathrm{g} / \mu \mathrm{l}$, respectively)."

The sentence should read:

The original article can be found online at https://doi.org/10.1007/ s00040-020-00755-8.

Y.-C. Huang

jameshuang@chbio.com.tw

$\triangle$ J. Wang

johnwang@gate.sinica.edu.tw

1 Biodiversity Research Center, Academia Sinica, Taipei, Taiwan

2 Present Address: CH Biotech R\&D Co., Ltd., Nantou City, Taiwan
For most injection batches we used $30 \mathrm{ng} / \mu \mathrm{l}$ of sgRNA and $300 \mathrm{ng} / \mu \mathrm{l}$ of Cas9 protein; for a few injection batches we used less ( $15 \mathrm{ng} / \mu \mathrm{l}$ and $150 \mathrm{ng} / \mu \mathrm{l}$, respectively).

The authors thank B. Çolak for bringing this to their attention. 